\title{
GAMBARAN HISTOPATOLOGI PARU TIKUS WISTAR SETELAH DIBERI PAPARAN ASAP ROKOK
}

\author{
Novera Herdiani ${ }^{1}$, Endah Budi Permana Putri ${ }^{2}$ \\ ${ }^{1,2}$ Fakultas Kesehatan, Universitas Nahdlatul Ulama Surabaya \\ e-mail: : novera.herdiani@unusa.ac.id ${ }^{1}$
}

\begin{abstract}
Cigarette smoke is the main cause of lung obstruction. One of the obstructions in real that is caused by cigarette smoke is oxidative stress. Oxidative stress trigger inflammation response occur and lung obstruction. Cigarette smoke able to cause lung histopathology changes like lungs obstruction on alveolus wall. Red dragon fruit extract tackle free radical then able to against the oxidative stress. The objective of this study to examines the image of rat lung histopathology under exposed cigarette smoke. Twenty four Wistar rats divided four groups: negative control, positive control, red dragon fruit extract treatment of 7,2 g/200 $\mathrm{g} \mathrm{WB}$, and red dragon fruit extract $10,8 \mathrm{~g} / 200 \mathrm{~g} \mathrm{WB}$. Negative control only given standard feed. Positive control given standar feed and exposed 21 cigarette per day. Treatment group given feed during 21 days. In the 22nd day rats be sacrificed, the lung taken out for observation and image of rat lung histopathology changes by making lung organ histopathology preparation hematoxicillin Eosion (HE) staining and observed under magnification light microscope 400x. The end result of the study indicate the finding of changes in lung histopathology such as obstruction level over the lung tissue higher, alveolar macrophage covered alveoli after being exposed cigarette smoke. Group which does not exposed cigarette smoke, lung alveolus macrophage in normal condition, there are no obstruction or alveolus macrophage occurred, its alveolar macrophage does no covering alveoli. Treatment group administered fruit dragon extract dose $10,8 \mathrm{~g} / 200 \mathrm{~g} \mathrm{WB}$ and dose $7,2 \mathrm{~g} / 200 \mathrm{~g} \mathrm{WB}$ seem almost the same with negative control treatment. Conclusion of the research is cigarette smoke expose can influence the number of alveolar macrophage on wistar rats. Suggestion very required further research on oxdative stress parameter.
\end{abstract}

Keywords: cigarret smoke, lung histopathology, wistar rat

Abstrak: Asap rokok adalah penyebab utama kerusakan paru-paru. Salah satu kerusakan yang nyata akibat asap rokok adalah stres oksidatif. Stres oksidatif memicu terjadinya respon inflamasi dan kerusakan paru. Asap rokok dapat menyebabkan perubahan histopatologi paru berupa kerusakan paruparu pada dinding alveolus. Ekstrak buah naga merah dapat menangkal radikal bebas sehingga dapat melawan stres oksidatif. Penelitian ini bertujuan untuk mengetahui gambaran histopatologi paru pada tikus yang diberi paparan asap rokok. Duapuluh empat ekor tikus wistar dibagi menjadi empat kelompok : kontrol negatif, kontrol positif, perlakuan ekstrak buah naga merah 7,2 g/200 g BB, dan ekstrak buah naga merah 10,8 g/200 g BB. Kontrol negatif hanya diberi pakan standar. Kontrol positif diberi pakan standar dan dipapar 2 rokok per hari. Kelompok perlakuan diberi pakan standar dan ekstrak buah naga merah di pagi hari dan setelah itu dipapar 2 rokok. Penelitian ini dilakukan selama 21 hari. Pada hari ke22 tikus dikorbankan, paru diambil untuk pengamatan perubahan gambaran histopatologi paru tikus dengan pembuatan preparat histologi organ paru dibuat pewarnaan Hematoksilin Eosin (HE) dan diamati di bawah mikroskop cahaya perbesaran 400x. Hasil penelitian menunjukkan adanya perubahan histopatologi paru berupa tingkat kerusakan jaringan paru semakin tinggi, makrofag alveolar menutupi alveoli setelah diberi paparan asap rokok. Kelompok yang tidak diberi paparan asap rokok, makroskopis alveoli paru dalam keadaan normal, kerusakan atau makrofag alveolar tidak terjadi, makrofag alveolarnya tidak sampai menutupi alveoli. Kelompok perlakuan yang diberi ekstrak buah naga merah dosis 10,8 g/200 g BB dan dosis 7,2 g/200 g BB terlihat hampir sama dengan kelompok kontrol negatif. Kesimpulan adalah paparan asap rokok dapat mempengaruhi jumlah makrofag alveolar pada tikus wistar yang diberi paparan asap rokok. Saran perlu dilakukan penelitian lebih lanjut parameter stres oksidatif.

Kata kunci: asap rokok, histopatologi paru, tikus wistar 


\section{PENDAHULUAN}

Merokok merupakan salah satu faktor penyebab terjadinya penyakit kardiovaskuler yang merupakan penyebab kematian terbesar di dunia. Word Health Organization telah memberikan peringatan bahwa dalam dekade 2020 - 2030 tembakau akan membunuh 10 juta orang per tahun, $70 \%$ diantaranya terjadi di negara-negara berkembang (WHO, 2008). Permasalahannya adalah menghilangkan kebiasaan merokok bukanlah hal yang mudah. Dalam asap rokok terkandung radikal bebas yang membahayakan tubuh, sehingga sementara ini perlu adanya inovasi untuk mengembangkan suatu produk yang dapat meminimalisir dampak negatif yang ditimbulkan oleh asap rokok. Menurut survey Perokok Muda Dunia 2007 (Global Youth Tobacco Surya) terdapat 6 dari 10 siswa yang berumur 13-15 tahun mempunyai satu atau lebih orangtua perokok, dan $65 \%$ dari mereka berada di lingkungan perokok (Reimondos, dkk., 2012).

Berdasarkan data RISKESDAS (2013), perilaku merokok penduduk usia $\geq 15$ tahun di Indonesia mengalami peningkatan yaitu sejumlah 36,3\%, dibandingkan RISKESDAS sebelumnya. Ditemukan 1,4\% perokok 10-14 tahun, 9,9\% perokok pada kelompok tidak bekerja, dan 32,3\% pada kelompok kuintil indeks kepemilikan terendah. Rerata jumlah batang rokok yang dihisap per hari per orang di Indonesia adalah 12 - 13 batang (setara satu bungkus). Jumlah perokok yang mengalami peningkatan terlihat juga pada sekitar $69 \%$ rumah tangga memiliki pengeluaran untuk rokok. Hal ini berarti minimal terdapat 1 orang anggota rumah tangga yang mengkonsumsi tembakau. Secara nasional $85,4 \%$ perokok usia 10 tahun keatas merokok di dalam rumah ketika bersama anggota rumah tangga lain. Sulit untuk menghentikan kebiasaan merokok pada masyarakat. Menurut Voges (2007), nikotin pada rokok dapat menyebabkan ketagihan dan gangguan pada jantung serta paru -paru.
Paparan asap rokok dapat membentuk radikal bebas di dalam tubuh. Radikal bebas adalah suatu elektron yang tidak memiliki pasangan dan akan terus berusaha mencari pasangan elektronnya sehingga dapat menjadi stabil. Jika elektron tidak mendapatkan pasangannya, maka akan terus menerus bergerak mencari pasangan elektronnya sehingga membentuk reaksi rantai. Hal ini dapat menyebabkan kerusakan sel dan menghancurkan DNA dalm sel-sel sehingga mempercepat timbulnya kanker dan banyak masalah kesehatan lainnya (Pham Huy, dkk., 2008).

Radikal bebas yang terdpat di dalam asap rokok dalam jumlah yang sangat tinggi dan memiliki sifat yang tidak stabil sehingga dapat merusak jaringan. Kelainan paru yang diakibat radikal bebas yang ada di dalam rokok akan menyebabkan gangguan atau kelainan pada saluran pernafasan, mulai dari trakea, bronkus, dan bronkiolus sampai pada alveoli paru (Nurliani, dkk 2012). Hasil penelitian yang dilakukan Kristianti (2008), didapat bahwa kelainan yang diakibatkan oleh radikal bebas pada tikus yang dipapar asap rokok terjadi peningkatan sel-sel radang. Pada jaringan alveolus paru terdapat sel makrofag alveolar. Sel ini merupakan perkembangan dari sel monosit yang terdapat pada leukosit, bertugas memfagosit benda asing di dalam alveolus paru (Djojodibroto, 2007). Konsekuensi untuk fungsi pertahanan leukosit (makrofag dan neutrofil) adalah leukosit dapat menyebabkan cedera jaringan dan memperpanjang peradangan karena produksi leukosit yang menghancurkan mikroba juga menciderai jaringan normal pejamu (Mitchell et al, 2009).

Radikal bebas dapat merusak biomakromolekul seperti karbohidrat, protein, lipid, dan asam nukleat. Radikal bebas membentuk perosidasi lipid dimana proses ini mengubah komponen membran sel dan membentuk senyawa toksis. Kerusakan oksidatif dan hal ini dapat membawa dampak yang lebih buruk bagi kesehatan. Oleh sebab itu, diperlukan tindakan 
yang tepat untuk menangani dan mencegah efek buruk dari radikal bebas yaitu dengan mengkonsumsi antioksidan.

Buah naga merah (Hylocereus polyrhizus) merupakan salah satu tanaman yang dapat dijadikan sebagai sumber antioksidan. Menurut Subagja (2013), manfaat dari nutrisi yang terdapat pada buah naga merah adalah (1) protein yang mampu meningkatkan metabolisme tubuh dan menjaga kesehatan jantung, (2) serat yang mampu mencegah kanker usus dan kencing manis, serta dapat menurunkan berat badan, (3) karoten yang mampu menjaga kesehatan mata dan meningkatkan daya kerja otak, (4) kalsium yam mampu menguatkan tulang, (5) zat besi yang mampu menjaga kesehatan darah, (6) vitamin $\mathrm{B}_{1}$ yang mampu mencegah penyakit demam, (7) vitamin $B_{2}$ yang mampu menambah selera makan, (8) vitamin $\mathrm{B}_{6}$ yang mampu menurunkan kadar kolesterol pada darah, dan (9) vitamin $\mathrm{C}$ yang mampu menjaga kesehatan kulit.

Berdasarkan penelitian yang dilakukan oleh Rebecca dkk (2010), buah naga merah mengandung polifenol terbanyak dibandingkan dengan species lainnya yaitu $86,13 \pm 17,02 \mathrm{mg}$ dalam $0,50 \mathrm{~g}$ ekstrak kering buah naga merah. Oleh karena kandungan yang tinggi akan polifenol yang dapat berperan sebagai antioksidan, maka dipilih buah naga merah sebagai sumber antioksidan pada penelitian ini.

Berdasarkan uraian yang telah dipaparkan di atas, maka dapat disimpulkan bahwa perlu dilakukan penelitian untuk mengetahui sejauh mana manfaat bahan alami buah naga merah sebagai salah satu antioksidan dalam upaya pencegahan pembentukan radikal bebas terhadap risiko stress oksidatif dalam tubuh dengan cara melihat histopatologi paru pada hewan coba. Oleh karena itu, dilakukan penelitian untuk mengetahui tingkat kerusakan paru tikus berdasarkan gambaran histopatologi paru tikus Wistar setelah diberi paparan asap rokok.

\section{METODE}

Jenis penelitian ini yaitu eksperimental laboratorium. Tahap in vivo yang digunakan adalah True Experimental Laboratory dengan post test only control group design. Rancangan perlakuan pada penelitian ini yaitu Rancangan Acak Lengkap (RAL). Sampel terdiri atas 24 ekor tikus jantan dipilih dengan cara random sampling untuk dibagi dalam satu kelompok kontrol negatif (normal), satu kelompok kontrol positif, dan dua kelompok perlakuan. Setiap kelompok terdiri dari 6 ekor tikus dengan penjelasan sebagai berikut :

1. Kelompok I adalah kontrol negatif (kelompok normal), tidak diberi paparan dan tidak diberi ekstrak buah naga merah (KN).

2. Kelompok II adalah kontrol positif, yang diberi air $1 \mathrm{ml}$ p.o selanjutnya diberi paparan asap rokok sebanyak 2 batang (KP).

3. Kelompok III adalah perlakuan yang diberi ekstrak buah naga merah dosis 7,2 g/200 g BB tikus/hari selanjutnya diberi paparan asap rokok sebanyak 2 batang (P1).

4. Kelompok IV adalah perlakuan yang diberi ekstrak buah naga merah dosis $10,8 \mathrm{~g} / 200 \mathrm{~g}$ BB tikus/hari selanjutnya diberi paparan asap rokok sebanyak 2 batang (P2).

Tahap in vivo dilakukan dengan memberikan ekstrak buah naga merah sesuai dosis yang telah ditetapkan. 24 tikus diadaptasikan selama 7 hari (minggu adaptasi). Setelah diadaptasikan 24 tikus kemudian dipilih secara random dan dibagi ke dalam 4 kelompok, yaitu kelompok kontrol negatif $(\mathrm{KN})$, kontrol positif (KP), perlakuan pertama (P1), dan perlakuan kedua (P2).Tahap lainnya meliputi diberi paparan asap rokok selama 21 hari, pada hari ke-22 tikus dikorbankan, paru diambil untuk pengamatan perubahan gambaran histopatologi paru tikus dengan pembuatan preparat histologi 
organ paru dibuat pewarnaan Hematoksilin Eosin (HE) dan diamati di bawah mikroskop cahaya perbesaran $400 \mathrm{x}$

Pemberian dosis buah naga merah kepada 2 kelompok perlakuan (P1 dan P2). Ekstrak buah naga merah diberikan dengan menggunakan sonde lambung sebelum makan pagi, dan dilaksanakan selama 21 hari dengan dosis masing-masing, yaitu dosis I (7,2 g/200 g BB tikus/hari) untuk kelompok P1, dosis II (10,8 g/200 g BB tikus/hari) untuk kelompok P2.

Asap rokok dari rokok kretek yang mengandung 2,90 mg Nikotin dan 44,30 mg Tar akan dipaparkan kepada kelompok KP, P1 dan P2. Tiga kelompok dipaparkan terhadap asap rokok sebanyak 2 batang selama 21 hari (Minggu II - Minggu IV) dimana diketahui akan menyebabkan stress oksidatif.

Penelitian ini dilaksanakan di laboratorium patologi veteriner UNAIR dan laboratorium kesehatan UNUSA. Hewan coba adalah tikus putih jenis Rattus norvegicus strain wistar jantan dewasa usia 3-4 bulan dengan berat rata-rata 150-200 gram.

\section{HASIL}

Gambaran histopatologi paru hewan coba pada kelompok penelitian ini menggunakan preparat dengan pewarnaan HE disajikan pada gambar berikut:

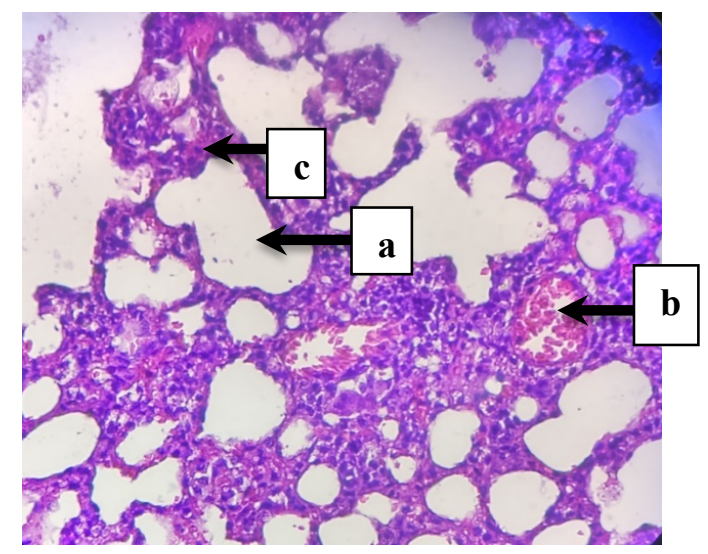

Gambar 1. Histopatologi paru tikus perbesaran 400x Hematoksilineosin (HE) kelompok kontrol negatif. Paru-paru normal a. Alveolus b. Pembuluh darah. c. Sel makrofag alveolar.

Dilakukan pengamatan dengan menggunakan mikroskop dalam 5 lapangan pandang dengan perbesaran 400x. Pengamatan ini dimulai dari sudut kiri, kanan, bagian atas, bagian bawah, serta bagian tengah dari preparat histopatologi paru. Setiap lapangan pandang diamati dan dilakukan perhitungan terhadap jumlah sel makrofag alveolar. Hasil pada sediaan histopatologi paru terhadap gambaran makrofag alveolar dengan pewarnaan HE.

Pada Gambar 1. terlihat bahwa kelompok kontrol negatif gambaran makroskopis alveoli paru dalam keadaan normal, dimana hasil pemeriksaan histopatologi paru kelompok negatif menunjukkan kerusakan atau makrofag alveolar tidak terjadi.

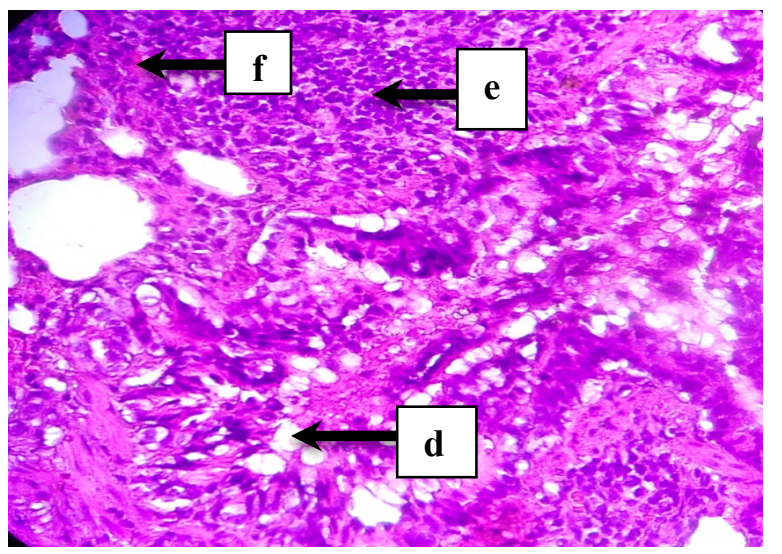

Gambar 2. Histopatologi paru tikus perbesaran 400x Hematoksilineosin (HE) kelompok kontrol positif pada penebalan dinding alveolus. Paru-paru abnormal d. Penyempitan diameter alveolus. e. Hiperplasia Bronchus Associated Lymphoid Tissue (BALT). f. Infiltrasi sel radang (makrofag alveolar).

Pada hasil pemerikasaan histopatologi paru tikus pada Gambar 2. kelompok kontrol positif terlihat adanya pola semakin tinggi kerusakan jaringan paru yang ditunjukkan dengan adanya makrofag alveolar, dimana makrofag alveolar terlihat menutupi alveoli, sedangkan pada kelompok kontrol negatif makrofag alveolarnya tidak sampai menutupi alveoli. Pada kelompok kontrol positif ditemukan adanya sel radang, yang 
ditandai dengan banyaknya sel makrofag dan neutrofil, nampak juga bahwa terdapat sel yang mengalami fibrosis, serta destruksi septum alveolar.

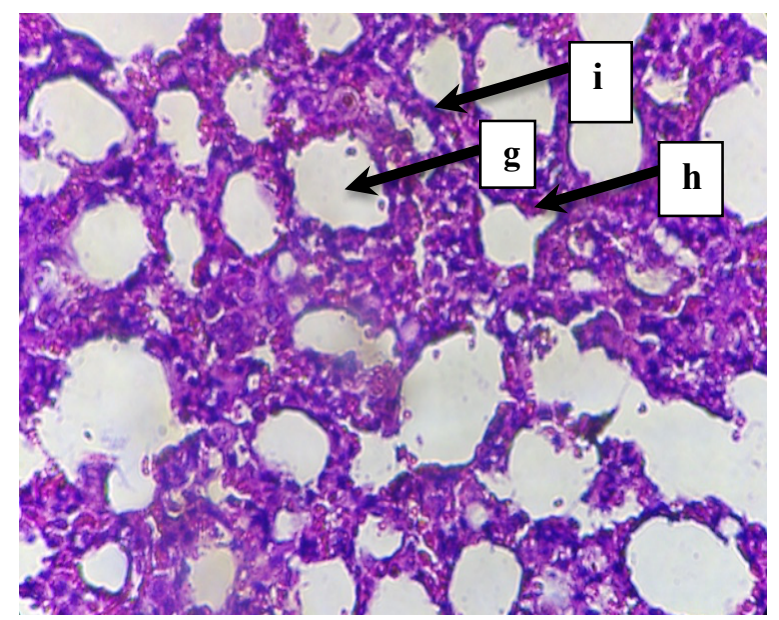

Gambar 3. Histopatologi paru tikus perbesaran 400x Hematoksilineosin (HE) kelompok perlakuan dosis 7,2 g/200 g BB. Paru-paru normal. g. Alveoli. Penebalan dinding alveolus mulai berkurang. $h$. Infiltrasi sel radang (makrofag alveolar). i. Septa alveolus sedikit menebal (abnormal).

Pada Gambar 3. kelompok perlakuan yang diberi ekstrak buah naga merah dosis 7,2 g/200 g BB terlihat adanya pola semakin kecil kerusakan paru yang ditunjukkan dengan berkurangnya makrofag alveolar yang menutupi alveoli. Pada kelompok perlakuan ekstrak buah naga merah dosis $7,2 \mathrm{~g} / 200 \mathrm{~g}$ BB masih terdapat sel yang mengalami peradangan, serta sel mengalami fibrosis dan desktruksi septum alveolar tetapi lebih sedikit dibandingkan kontrol positif.

Pada Gambar 4. kelompok perlakuan yang diberi ekstrak buah naga merah dosis $10,8 \mathrm{~g} / 200 \mathrm{~g}$ BB terlihat adanya pola semakin kecil kerusakan paru yang ditunjukkan dengan jumlah makrofag alveolar yang semakin sedikit dan alveoli terlihat tidak ditutupi oleh makrofag alveolar. Histopatologi paru kelompok perlakuan yang diberi ekstrak buah naga merah dosis $10,8 \mathrm{~g} / 200 \mathrm{~g}$ BB terlihat hampir sama dengan kelompok kontrol negatif.

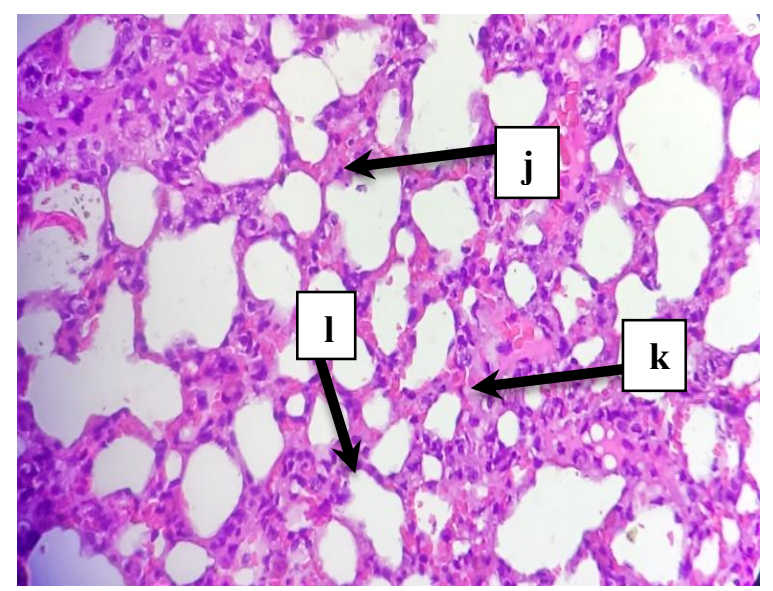

Gambar 4. Histopatologi paru tikus perbesaran

400x Hematoksilineosin (HE) kelompok perlakuan

dosis 10,8 g/200 g BB 2. Paru-paru normal. j.

Alveoli. k. Septa alveolus normal. I. Sel makrofag alveolar.

\section{PEMBAHASAN}

Pada kelompok kontrol negatif menunjukkan hubungan antar alveolus yang rapat pada kelompok yang tidak dipapar asap rokok dimana matriks ekstraseluler terdiri dari serabut kolagen dan elastin masih utuh. Lumen alveolus nampak normal tidak membesar yang umum terjadi apabila ada kelainan paru-paru. Gambaran makroskopis alveoli paru dalam keadaan normal, dimana hasil pemeriksaan histopatologi paru kelompok negatif menunjukkan kerusakan atau makrofag alveolar tidak terjadi. Hal ini disebabkan paru-paru tersebut tidak terpapar dengan toksikan yang terkandung dalam asap rokok, sehingga sel-selnya tidak mengalami kerusakan (Marianti, 2009). Keadaan ini tampak sedikit berbeda dengan paru-paru tikus pada kelompok kontrol positif yang dipapar dengan asap rokok secara kontinyu, terlihat adanya keruskan pada struktur mikroanatomi paruparunya, dimana makrofag alveolar terlihat 
menutupi alveoli. Hal ini disebabkan telah terjadi perusakan sel-sel epithelium dan endothelium pada alveolus oleh toksikan pada asap rokok.

Beberapa penelitian membuktikan, bahwa paparan asap rokok dapat mempengaruhi jumlah aktivasi makrofag alveolar. Penelitian yang dilakukan Marwan dkk (2005), Lopes dkk (2013) menunjukkan bahwa tikus yang dipapar asap rokok, jumlah makrofag alveolar secara signifikan lebih banyak dibanding dengan yang tidak terpapar asap rokok. Paparan asap rokok pada hewan coba tikus menyebabkan terjadinya kerusakan paru-paru berupa kerusakan pada dinding alveolus. Namun, tingkat kerusakan pada dinding alveolus semakin menurun seiring dengan meningkatnya dosis pemberian ekstrak buah naga merah

Asap rokok menimbulkan efek kerusakan histopatologi paru tikus, seperti destruksi septum alveolar, edema paru, dan infiltrasi sel radang (Fauzan, 2003). Pada pengamatan sediaan preparat, destruksi septum alveolar berupa adanya septum alveolar yang mengalami penipisan, atrofi, dan pada beberapa tempat terdapat keruskan yang membentuk bulat yang disertai pembesaran duktus dan sakus alveolus. Sedangkan edema paru ditemukan adanya alveolus berisi cairan, sehingga sangat sulit ditemukan sel dalam cairan tersebut, dan ditandai dengan bertambahnya longgarnya septum alveolar. Kemudian infiltrasi sel radang ditemukan adanya sequestrasi leukosit polimorfonuklear terutama neutrofil pada mikrovaskuler pulmoral (Bloom et al, 2002). Safitri (2010) menyatakan bahwa komponen gas asap rokok adalah $\mathrm{CO}$, amoniak, asam hidrosianat, nitrogen oksida, dan formaldehid. Partikelnya berupa tar, indol, nikotin, karbarzol, dan kresol. Zat ini beracun, mengiritasi, dan menimbulkan kanker (karsinogen).

Paru merupakan organ dalam tubuh yang berhubungan langsung dengan udara luar, sehingga paru mempunyai kemungkinan terpajan bahan yang berbahaya (partikel, gas toksik, mikroorganisme patogen) (Guyton, 2006). Partikel yang masuk dalam paru ukurannya sangat beragam, dan paru memiliki mekanisme pertahanan untuk melindungi diri dari bahan yang mengenainya. Partikel berukuran $>10 \mu \mathrm{m}$ tertangkap di dalam rongga hidung, yang berukuran diantara 5-10 $\mu \mathrm{m}$ tertangkap di bronkus percabangannya, sedangkan yang berukuran $<3 \mu \mathrm{m}$ dapat masuk dalam alveoli (Djojodibroto, D., 2007). Partikel yang terdisposisi akan mengaktivasi makrofag alveolar untuk melakukan proses fagositosis. Makrofag alveolar berasal dari monosit darah dan termasuk dalam fungsi pertahanan leukosit. Makrofag alveolar merupakan pertahanan yang paling akhir dan paling penting terhadap invasi benda asing ke dalam paruparu (Guyton, 2006).

Partikel asing dalam alveolus menyebabkan respon peradangan. Peradangan (inflamasi) adalah suatu reaksi kompleks terhadap agen atau bahan yang merugikan. Respon peradangan berkaitan erat dengan proses perbaikan. Peradangan berfungsi untuk menghancurkan, mengencerkan, atau membatasi agen yang merugikan, dan memicu terjadinya serangkaian proses yang mencoba untuk memulihkan dan mengganti jaringan yang rusak. Saat terjadi peradangan, proses aktivasi dan fagositosis sel leukosit membebaskan juga ROS tidak hanya dalam fagolisosom melainkan ke dalam ruang ekstrasel. Produk tersebut mampu menimbulkan cedera endotel dan kerusakan jaringan sehingga dapat memperkuat cedera awal. Serangkaian proses tersebut menyebabkan pada perokok terjadi akumulasi makrofag dan neutrofil di alveolus (Mitchell et al., 2009).

Buah naga merah dapat dijadikan sumber antioksidan yang dapat memangsa radikal bebas yang berasal dari asap rokok, sehingga dapat melawan stres oksidatif dan menolak kerusakan lebih lanjut, dan tidak dapat merangsang makrofag alveolar. Akibat dari kurangnya rangsangan pada makrofag maka sel paru-paru tidak ada pengaktifan makrofag alveolar yang menyebabkan 
bertambahnya jumlah makrofag alveolar (Anggraini dkk, 2012). Kerusakan oksidatif dapat dihalangi oleh senyawa antioksidan melalui reduksi dengan radikal bebas, membentuk ketat dengan senyawa logam katalitik dan menangkap oksigen. Antioksidan adalah semua senyawa yang dapat meredam dampak negatif dari oksidan, termasuk dalam penghambatan dan penghentian kerusakan oksidatif terhadap suatu molekul target (Miguel et $a l, 2010)$.

Hasil yang diperoleh dari penelitian secara preventif menunjukkan bahwa kelompok yang diberi paparan asap rokok disertai dengan pemberian ekstrak buah naga merah menunjukkan adanya penurunan jumlah makrofag dibandingkan dengan kelompok yang hanya dipapar asap rokok tanpa diberi ekstrak buah naga merah. Rerata jumlah makrofag yang hanya dipapar asap rokok sebesar $50,00 \pm 2,236$. Jumlah makrofag pada kelompok preventif yang mendapat ekstrak buah naga merah dosis $10,8 \mathrm{~g} / 200 \mathrm{~g}$ BB dapat menurunkan atau mencegah kenaikan jumlah makrofag dengan rerata $16,80 \pm 1,483$. Penelitian ini sejalan dengan penelitian sebelumnya yang dilakukan oleh Lee et al (2014) yang menyatakan bahwa tikus yang dipapar asap rokok dan diberi antioksidan dapat menghambat meningkatnya jumlah makrofag alveolar.

\section{KESIMPULAN}

Berdasarkan hasil penelitian yang telah dilakukan dapat disimpulkan bahwa:

1. Histopatologi paru kelompok perlakuan yang diberi ekstrak buah naga merah dosis $10,8 \mathrm{~g} / 200 \mathrm{~g}$ BB dan dosis 7,2 g/200 g BB terlihat hampir sama dengan kelompok kontrol negatif yang tidak diberi paparan asap rokok.

2. Paparan asap rokok dapat mempengaruhi jumlah makrofag alveolar pada tikus wistar yang diberi paparan asap rokok.

\section{SARAN}

1. Perlu dilakukan penelitian lebih lanjut terhadap parameter stress oksidatif yang lainnya seperti IL-1, GSH untuk mengetahui mekanisme kerja ekstrak buah naga merah secara biomolekuler.

2. Buah naga merah dapat dikonsumsi untuk meredam pengaruh radikal bebas dari asap rokok.

\section{UCAPAN TERIMAKASIH}

Penelitian ini merupakan bagian dari penelitian yang mendapat hibah dari Kemenristekdikti berupa Penelitian Dosen Pemula (PDP) dengan kontrak No. 065/SP2H/LT/K7/KM/2018. Terimakasih juga pada Universitas Nahdlatul Ulama Surabaya atas support penelitian yang diberikan.

\section{DAFTAR PUSTAKA}

Anggraini, H., Neni S dan Pudjadi. 2012. Pengaruh Pemberian Jus Mengkudu Terhadap Reactive Oxygen Intermediate (ROI) Makrofag Bronchoalveolar Tikus Yang Terpapar Asap Rokok. Seminar Hasil-Hasil Penelitian - LPPM Unimus. ISBN 978-60218809-0-6.

Bloom W, Fawcett D., 2002. Buku Ajar Histologi. $12^{\text {th }}$ ed. Jakarta: EGC. Pp: 632-635.

Djojodibroto, D., 2007. Respirologi (Respiratory Medicine). Jakarta: Buku Kedokteran EGC. Fauzan., 2003. Penentuan Kadar Nikotin Dalam Asap Rokok. Jurnal Ekologi Kesehatan. pp: 273-274.

Guyton AC, Hall JE., 2006. Textbook of Medical Phatology W. B Saunders Co.

Kristianti, JB., dkk. 2008. Buku Ajar Fitokimia. Airlangga University Press Surabaya. 
Lee, SG., Bohkyung K., Yue Y., Tho XP., Youngki P., Jose M., Sung IKI., Oek KC and JiYoung L. 2014. Berry Anthocyanins Suppress The Expression And Secretion Of Proinflammatory Mediators In Macrophages By Inhibiting Nuclear Translocation Of NF$\mathrm{kB}$ Independent Of NRF2-Mediated Mechanism. Journal of nutritional Biochemistry 25, 404-411.

Lopes, AG., Thiago SF., Renata TN., Manuella L., Karla MPP., Ari MS., Ricardo MB., Antonio JRS., Samuel SV., and Luis CP. 2013. Antioxidant Action Of Propolis On Mouse Lungs Exposed To Short-term Cigarette Smoke, Bioorganic And Medicinal Chemistry. Vol 21. No 24 Hal 7570 - 7577.

Marianti, Aditya. 2009. Aktifitas Antioksidan Jus Tomat Pada Pencegahan Kerusakan Jaringan Paru-Paru Mencit Yang Dipapar Asap Rokok. Jurnal Biosaintifika 1: 1-10.

Marwan E. Widjajanto, dan S. Karyono. 2005. Pengaruh Pemberian Ekstrak Biji Jinten Hitam (Nigella sativa) Terhadap Kadar GSH, MDA, Jumlah Serta Fungsi Sel Makrofag Alveolar Paru Tikus Wistar Yang Dipapar Asap Rokok Kronis. Malang. Universitas Brawijaya, Hal 45-64.

Miguel, MG. 2010. Antioxidant Activity of Medical And Aromatic Plants A Review. Flavour Fragr J. 25, 291-312.

Mitchell RN., Kumar V., Abbas AK., Fausto N., 2009. BS Dasar Patologis Penyakit. Jakarta: Buku Kedokteran EGC.

Nurliani, A., Santoso, dan Rusmiati. 2012. Efek Antioksidan Ekstrak Bulbus Bawang Dayak (Eleutherine palmifolia) Pada Gambaran Histopatologi Paru-Paru Tikus Yang Dipapar Asap Rokok. Jurnal Bioscientiase. Volume 9, Nomor I, Hal 60-69.

Pham-Huy LAP, H He, dan C Pham-Huy. 2008. Free Radicals, Antioxidants in Disease and Health. Int J Biomed Sci., Vol. 4, p. 89-96.
Rebecca OPS, AN Boyce, dan S Chandra. 2010. Pigment Identification and Antioxidant Properties of Red Dragon Fruits (Hylocereus polyrhizus). African Journal of Biotechnology, Vol. 9, No. 10, p. 1450-1454. Reimondos A, ID Utomo, P McDonald, T Hull, H Suparno, dan A Utomo. 2012. Merokok dan Penduduk Dewasa Muda di Indonesia. Australia The Australian National University, hal. 3-17.

RISKESDAS. 2013. Riset Kesehatan Dasar. Jakarta Badan Penelitian dan Pengembangan Kesehatan Kementerian Kesehatan RI. Akses internet online. www.litbang.depkes.go.id/sites/download/r kd2013/Laporan_Riskesdas2013.PDF [diakses 6 Juni 2017].

Safitri, wenny. 2010. Bahaya Merokok Bagi kesehatan. UMM. http://w3nny.student.umm.ac.id/2017/06/03 bahaya-merokok-bagi-kesehatan/Diakses tanggal 3 Juni 2017.

Subagja HP. 2013. Saktinya Buah Naga dan Delima: Tangkal Penyakit-Penyakit Mematikan. Jogyakarta: FlashBooks, hal. 10-71.

Voges, E. 2007. Tobacco Encyclopedia. Tabac Journal International, Mainz, Germany, $279 \mathrm{p}$.

World Health Organization. 2008. WHO Report On The Global Tobacco Epidemic 2008. WHO publisher, New York: 3-8. 